\title{
PERUBAHAN RESPON PENDENGARAN KARENA PEMAKAIAN EARPHONE
}

\author{
Dewi Rossalia \\ Program Studi S1 Fisika, Fakultas Sains dan Teknologi, Universitas \\ Airlangga \\ Email: dewi.rossalia@gmail.com
}

\begin{abstract}
Abstrak
Telah dilakukan penelitian tentang perubahan respon pendengaran karena pemakaian earphone terhadap karyawan bagian call center yang meliputi pengukuran intensitas kebisingan pada earphone yang biasa digunakan oleh karyawan, pengisian kuesioner dan pengukuran ambang pendengaran dengan audiometer. Penelitian ini bertujuan untuk mengetahui pengaruh kebisingan suara yang dikeluarkan oleh earphone terhadap ambang dengar manusia, mengetahui adanya hubungan lama masa kerja dan usia terhadap gangguan pendengaran pada karyawan call center. Rancangan penelitian eksperimen dengan Randomized Post Test Only Control Group Design. Setelah dilakukan pengambilan data intensitas kebisingan yang dikeluarkan oleh earphone adalah sekitar 59-62 dB. Untuk mengkaji pengaruh intensitas kebisingan terhadap pendengaran karyawan dilakukan pengukuran audiometer pada karyawan yang terpapar kebisingan earphone (kelompok perlakuan) dan karyawan yang tidak terpapar kebisingan earphone (kelompok kontrol). Data-data yang dihasilkan diolah dengan menggunakan uji T dua sampel bebas (chi-square t-test), Chi-Square test, Anova test dan Mann-Whitney test. Dari hasil penelitian didapatkan hubungan yang bermakna antara kebisingan earphone terhadap ambang pendengaran karyawan kelompok perlakuan dengan kelompok kontrol $(\mathrm{p}<0,05)$.
\end{abstract}

Kata kunci : kebisingan earphone, gangguan pendengaran.

\section{Latar Belakang Masalah}

Masalah

kerusakan

pendengaran merupakan salah satu

permasalahan yang menjadi pusat perhatian masyarakat internasional,

khususnya di negara-negara maju

seperti Jepang, Jerman, Belanda,

Inggris dan Amerika Serikat. Di 
negara-negara tersebut masyarakat secara proaktif mendorong lembagalembaga terkait untuk membuat suatu aturan yang melindungi masyarakat luas dari pengaruh kerusakan pendengaran.

Di Indonesia masalah kerusakan pendengaran merupakan masalah yang kurang populer, khususnya bagi pekerja yang bekerja di lingkungan yang dapat menyebabkan kerusakan pendengaran. Hal ini tidak terlepas dari kurangnya pengetahuan para pekerja tentang kerusakan pendengaran, gejala dan keadaan yang menandai seseorang menderita kerusakan pendengaran.

Telinga manusia mempunyai ambang batas pendengaran, dengan frekuensi $20-2000 \mathrm{~Hz}$ dan intensitas suara hingga $80 \mathrm{~dB}$ (desibel). Bila suara yang didengarkan masih dalam batas normal, tidak menjadi masalah. Yang menjadi masalah adalah ketika mendengarkan suara dengan intensitas lebih dari $80 \mathrm{~dB}$, karena suara dengan intensitas tinggi mempengaruhi reseptor suara pada telinga (Hamdali, 2006).

Seiring dengan perkembangan teknologi yang semakin pesat, makin banyak pula perusahaan yang dilengkapi dengan alat-alat modern. Salah satunya adalah perusahaan telekomunikasi. Perusahaanperusahaan telekomunikasi ini memberikan keuntungan dan kerugian. Salah satu keuntungannya adalah membantu memberikan informasi secara cepat kepada masyarakat, sedangkan kerugiannya adalah terjadinya penurunan pendengaran yang telah dirasakan langsung oleh para pekerja call center. Masalah yang dihadapi oleh 
para pekerja call center ialah adanya kebisingan suara yang ditimbulkan oleh earphone dalam waktu cukup lama, sehingga dapat mengganggu para pekerja dan menimbulkan kerugian terutama pada aspek kesehatan, yaitu terjadinya penurunan pendengaran dan bahkan bisa menjadi tuli pendengaran.

Kerusakan pendengaran akibat pemakaian earphone disebabkan oleh gelombang bunyi yang melakukan penekanan pada selaput kendang telinga, bila ini terjadi terus-menerus dan dalam jangka waktu yang lama akan menyebabkan kerusakan pendengaran yang berakibat menjadi tuli pendengaran akibat bising. Jadi pemakaian earphone secara terus menerus akan mengurangi kemampuan telinga untuk mendengar dan menghantarkan informasi ke otak (Sears, Zemansky,
1982).

Hamdali (2006) melakukan poling terhadap sejumlah responden dan melaporkan, bahwa pemakaian earphone dengan frekuensi dan intensitas lebih

dari $80 \mathrm{~dB}$ bisa menyebabkan ketulian. Dari pernyataan tersebut dapat dijadikan acuan dalam mengembangkan penelitian ini. Pada penelitian ini yang diukur adalah pengaruh pemakaian earphone pada karyawan bagian operator call center dalam jangka waktu lama dengan intensitas tinggi melebihi ambang batas pendengaran.

Penelitian ini menggunakan Audiometer nada murni dan Sound Level Meter untuk mengetahui pengaruh penggunaan earphone pada pendengaran. Sound Level Meter berskala $\mathrm{dB}$ digunakan untuk 
mengukur intensitas kebisingan, dan taraf intensitas kebisingan sedangkan Audiometer nada murni earphone yang digunakan oleh para adalah suatu alat yang berfungsi karyawan operator call center antara untuk mengukur ambang dengar 59-62 dB. Hasil pengukuran taraf manusia. Pengukuran ambang dengar manusia bertujuan untuk mendeteksi adanya kelainan pada pendengaran manusia.

\section{Hasil Pengukuran Taraf Intensitas}

\section{Kebisingan}

Dari pengukuran yang telah dilakukan, didapatkan hasil perhitungan taraf intensitas kebisingan. Dari hasil perhitungan ini menunjukkan perbedaan tingkat intensitas kebisingan (perbedaan tingkat tekanan bunyi) pada tiap lokasi PT. Telkom. Bila dilihat dari data taraf intensitas kebisingan di area operator call center antara 60-64 $\mathrm{dB}$, di area administrasi antara 48-51 $\mathrm{dB}$, di area teknisi antara 49-51 dB, intensitas kebisingan dari lokasilokasi tersebut dihasilkan rata-rata kurang dari NAB $(<85 \mathrm{~dB})$. Nilai ini memenuhi persyaratan nilai ambang batas (NAB) yang telah ditetapkan di Indonesia berdasarkan Keputusan Menteri Tenaga Kerja Nomor : KEP51/MEN 1999, yang ditetapkan NAB sebesar 85 dB. Jadi lokasi-lokasi tersebut mempunyai taraf intensitas kebisingan rendah sehingga masih berada dalam taraf aman.

\section{Hasil Pengukuran Ambang}

\section{Pendengaran}

Dari hasil uji statistik didapatkan adanya perbedaan yang bermakna antara ambang pendengaran rata-rata telinga kanan 
maupun telinga kiri, pada kelompok perlakuan dan kelompok kontrol.

Penurunan ambang

pendengaran berdasarkan gambar grafik ambang pendengaran rata-rata karyawan PT. Telkom pada setiap frekuensi adalah termasuk tuli ringan dengan kehilangan berkisar 15-40 dB melintasi seluruh rentang frekuensi.

Perbandingan ambang pendengaran rata-rata kelompok perlakuan dan kelompok kontrol dapat dilihat dalam Grafik 4.2. Dari grafik ini dapat dilihat perbedaan ambang pendengaran kelompok perlakuan dan kelompok kontrol yang berbeda-beda taraf intensitasnya. Sedangkan besarnya tekanan yang diberikan pada selaput kendang telinga jika intensitas suara hingga $80 \mathrm{~dB}$ adalah $884,94 \times 10^{-4}$ Pa. Hal ini dapat dijelaskan bahwa gelombang bunyi sering kali disebut sebagai gelombang tekanan $\left(I=\frac{1}{2} \frac{p_{0}}{\rho v}\right)$. Jadi intensitas yang semakin besar akan menyebabkan tekanan yang tinggi pada gelombang bunyi, dimana masuknya gelombang bunyi ke telinga mengakibatkan bergetarnya partikel-partikel udara pada selaput kendang pada frekuensi dan amplitudo tertentu. Gelombang bunyi melakukan penekanan pada selaput kendang telinga, bila ini terjadi terus-menerus dan dalam jangka waktu yang lama akan menyebabkan kerusakan pendengaran yang berakibat menjadi tuli pendengaran akibat bising (Sears, Zemansky, 1982).

Pada Grafik 4.2 terdapat perbedaan ambang pendengaran antara telinga kanan dan kiri yang simetris, hal ini disebabkan karena karyawan pada waktu kerja ada yang 
Jurnal Biosains Pascasarjana Vol. 21 (2019) pp

(C) (2019) Sekolah Pascasarjana Universitas Airlangga, Indonesia

menggunakan salah satu telinga

secara terus-menerus sehingga dapat

ditemui perbedaan tingkat gangguan

pendengaran yang cukup besar

antara telinga kiri dan kanan.

Mekanisme kerusakan telinga

akibat kebisingan adalah

sebagai berikut:

Masuknya gelombang bunyi dengan

intensitas yang kuat mengakibatkan

bergetarnya partikel-partikel udara

pada membran timpani yang

dilanjutkan melalui foramen ovale ke

perilim dan endolim yang

selanjutnya menggetarkan membran

basalis lebih kuat daripada keadaan

normal, keadaan ini menyebabkan

terjadinya perubahan patologis

sebagai berikut :

1. Penurunan aliran

darah pada koklea

sehingga terjadi

penurunan oksigen untuk

metabolisme yang

mengakibatkan

perubahan

metabolisme pada

organ corti dan

jaringan lain di

koklea atau

perubahan dari

komposisi ion-ion

dari endolim

maupun perilim

2. Kerusakan sel-sel

sensoris ditandai

dengan adanya

kerusakan atau

degenerasi dari

sel-sel sensoris

terutama sel-sel

rambut bagian

luar, termasuk

disini perubahan

elastisitas, fusi 
dan bahkan total dapat dikatakan homogen. Seiring destruksi dari dengan bertambahnya usia akan stereosilia menyebabkan berkurangnya (Suheryanto, sensitivitas pendengaran yang 1994).

dikenal dengan istilah presbycusis. Apabila seseorang bekerja di tempat

Distribusi Usia dan Lama Masa Kerja Karyawan PT. Telkom

Berdasarkan uji yang dilakukan, distribusi usia dan lama masa kerja antara kelompok perlakuan dengan kelompok kontrol tidak ada perbedaan. Distribusi usia dan lama masa kerja antara kelompok perlakuan dengan kelompok kontrol yang sama ini digunakan untuk dapat membandingkan pengaruh kebisingan earphone antara kedua kelompok.

Berdasarkan hasil uji statistik dari usia dan lama masa kerja disimpulkan bahwa kedua kelompok kerja yang bising untuk pertama kalinya pada usia 40 tahun atau lebih, biasanya akan lebih rentan terhadap trauma akibat kebisingan. Oleh karena itu penetapan usia sampel antara 20-35 tahun karena rentang usia itu adalah usia produktif dan untuk menghindari presbycusis. Untuk mengetahui pengaruh lama masa kerja dan usia terhadap ambang pendengaran maka disajikan sebagai berikut :

\section{Lama masa kerja}

Pada penelitian ini ternyata tidak terdapat hubungan yang 
bermakna antara lama masa kerja terhadap ambang pendengaran pada karyawan call center. Hal ini dikarenakan oleh :

1. Karyawan mempunyai lama masa kerja yang kurang dari 10 tahun.

2. Karyawan jarang menggunakan radio atau walkmann, sehingga selama masa kerja hanya menerima kebisingan dari earphone call center.

3. Karyawan selama masa kerja menggunakan earphone dengan intensitas yang relatif rendah.

4. Karyawan selama masa kerja menggunakan earphone tidak menetap pada salah satu telinga saja, tapi bergantian.

Dari sini jelas terlihat bahwa akan ada pengaruh pada ambang pendengaran dengan semakin bertambahnya lama masa kerja.

Usia

Pada penelitian ini ternyata tidak terdapat hubungan yang bermakna antara usia terhadap ambang pendengaran pada karyawan call center. Hal ini dikarenakan oleh:

1. Karyawan mempunyai usia yang relatif muda, sehingga relatif lebih tahan terhadap kebisingan earphone.

2. Karyawan jarang menggunakan radio atau walkmann.

3. Karyawan selama bekerja menggunakan earphone dengan intensitas yang relatif rendah.

4. Karyawan selama bekerja menggunakan earphone tidak menetap pada salah satu telinga saja, tapi bergantian. 
Dari sini jelas terlihat bahwa akan ada pengaruh pada ambang pendengaran dengan semakin bertambahnya usia.

\section{Pengaruh Kebisingan Earphone}

Terhadap Ambang Pendengaran Karyawan PT. Telkom

Pada penelitian ini ternyata didapatkan pengaruh yang bermakna dari kebisingan earphone terhadap ambang pendengaran karyawan PT. Telkom. Tiga belas orang dari kelompok perlakuan menunjukkan gambaran audiogram normal, hal ini dapat dijelaskan sebagai berikut : Karyawan mempunyai usia yang relatif muda terutama pada awal bekerja, dan mempunyai lama masa kerja yang baru 4 bulan, sehingga relatif lebih tahan terhadap kebisingan earphone. Selama bekerja karyawan tersebut senantiasa menggunakan alat pelindung telinga sehingga relatif lebih tahan terhadap kebisingan. Karyawan selama bekerja menggunakan earphone dengan intensitas yang relatif rendah. Karyawan selama bekerja menggunakan earphone tidak menetap pada salah satu telinga saja, tapi bergantian.

Pengaruh yang bermakna dari kebisingan earphone terhadap ambang pendengaran karyawan PT. Telkom ini disebabkan oleh gelombang bunyi yang melakukan penekanan pada selaput kendang telinga, bila ini terjadi terus-menerus dan dalam jangka waktu yang lama akan menyebabkan kerusakan pendengaran yang berakibat menjadi tuli pendengaran akibat bising. Jadi pemakaian earphone secara terus menerus akan mengurangi kemampuan telinga untuk 
mendengar dan menghantarkan informasi ke otak (Sears, Zemansky, 1982).

Berbagai upaya pengendalian sudah dilakukan tetapi belum optimal, yaitu antara lain :

1. Pengendalian secara teknik

Dalam masalah pengendalian kebisingan secara teknis yang mencakup pengendalian pada sumber bunyi belum dilaksanakan secara baik.

2. Pengendalian secara administrasi Upaya pengendalian secara administrasi sudah dilakukan oleh pihak perusahaan yakni, dengan pergantian/rotasi pekerjaan, sehingga upaya ini dapat mengurangi penurunan pendengaran. Pengendalian administrasi yang juga sudah dilakukan adalah pemeriksaan kesehatan telinga karyawan. Tetapi pemeriksaan ini dilakukan sekali tiap tahunnya. Menurut Iskandar (2003) pemeriksaan pendengaran berkala pada pekerja yang sudah bekerja sebaiknya dilakukan adalah pemeriksaan kesehatan awal pada saat tenaga kerja masuk bekerja dan selanjutnya adalah pemeriksaan berkala.

3. Pemakaian Alat Pelindung Telinga (APT)

Upaya pemakaian alat pelindung telinga yang belum dilaksanakan secara baik, yaitu dengan alat pelindung khusus yang disebut micropgones, untuk menyaring bunyi yang masuk ke telinga dan menurunkan kebisingan antara 25-40 dB.

Gangguan pendengaran akibat pemakaian earphone adalah suatu bentuk tuli konduksi akibat alat pendengaran terpapar oleh suara 
bising yang terus-menerus dalam jangka waktu yang lama.

$$
\text { Selain mengakibatkan }
$$

gangguan pendengaran, bising

dengan frekuensi dan intensitas yang

tinggi menyebabkan gangguan

psikologis berupa gangguan tidur,

gangguan komunikasi dan gangguan

emosional. Selanjutnya dapat

mengakibatkan penurunan

produktivitas dan kualitas sumber

daya manusia. (Gabriel, 2001).

\section{DAFTAR PUSTAKA}

Ackerman, E., Ellis, BML dan

Williams, LE., 1988, Ilmu Biofisika,

Terjemahan

Redjani dan Abdulbasir, Airlangga University Press, Surabaya

Andi, 2002, 10 Model Penelitian dan Pengolahannya dengan SPSS, Wahana Komputer , Semarang

Anonemues, Macam-Macam

Earphone, http://www.abeir.com, 14 Mei 2006

Cameron, R.J., Skrofonick, G.J., Grant, M.R., 2006, Fisika Tubuh Manusia, Edisi II, CV. Sagung Seto, Jakarta
Gabriel, J.F., 2001, Fisika Lingkungan, Edisi Pertama, Hipokrates, Jakarta, hal: 163-172

Giancoli, C.D., 2001, Fisika, Edisi Kelima, Erlangga, Jakarta, hal: 407424

Hamdali, 2006, Akibat Pemakaian

Earphone, Artikel Jawa Pos, Surabaya

Hernomo, Soekesi, 1998, Anatomi dan Fisiologi Telinga, Artikel Fakultas

Kedokteran
Airlangga: RSU
Surabaya, hal: $1-8$

Siswanto, A., 1991, Kebisingan, Balai Hiperkes dan Keselamatan Kerja Jawa

Timur Departemen Tenaga Kerja, Surabaya

Suheryanto, R, 1994, Pengaruh

Kebisingan Mesin Pabrik

Tekstil Terhadap

Pendengaran Karyawan,

Karya Akhir Untuk

Memperoleh Ijasah Keahlian

Ilmu Penyakit THT Fakultas

Kedokteran Unair/RSUD Dr.

Soetomo, Surabaya

Suma'mur, Pk, 1998, Higene Perusahaan dan Kesehatan Kerja, Gunung Agung,

Jakarta, hal: 57-69

Suwento, R,Zizlavsky, 2003,

Masalah Kesehatan Telinga

Yang Menyebabkan

Gangguan Pendengaran dan

Ketulian Serta Kondisi

Infrastruktur Saat Ini. Temu

konsultasi Perumusan 


\author{
Strategi Nasional \\ Penanggulangan Gangguan \\ Pendengaran dan Ketulian \\ (PGPKT), Bogor hal 1-13
}

Tipler, A.P., 1998, Fisika untuk

Sains dan Teknik, Edisi Ketiga,

Erlangga, Jakarta,

hal: 389-390, 505-534

Wiyadi, M.S., 1979, Penyebab

Gangguan Pendengaran,

Artikel Fakultas Kedokteran

Universitas Airlangga :

RSUD Dr. Soetomo,

Surabaya hal 1-15

Yanri, Z., Haryani, S. dan Yusuf, M.,

2002, Himpunan Peraturan

Perundangan

Kesehatan Kerja, PT.

Citratama Bangun Mandiri, Jakarta, hal: 211-215

Zemansky, Sears, 1994, Fisika

Untuk Universitas I

Mekanika. Panas. Bunyi,

Yayasan Dana Buku

Indonesia, Jakarta. 